M. Nashruddin | Model Kewirausahaan Agribisnis Pada Yayasan Pondok Pesantren Darul Yatama Wal Masakin (Yaponpes-Dayama)) Jerowaru- Lombok Timur

\title{
Model Kewirausahaan Agribisnis Pada Yayasan Pondok Pesantren Darul Yatama Wal Masakin (Yaponpes-Dayama)) Jerowaru- Lombok Timur
}

\author{
Oleh: \\ Muhammad Nashruddin \\ Prodi. Agribisnis Universitas Gunung Rinjani \\ Email: nashbkp@gmail.com
}

\begin{abstract}
Abstrak:
Penelitian ini merupakan penelitian deskriptif dengan metode analisis secara kualitatif. Tujuan penelitian ini adalab untuk mengetabui model kewirausahaan agribisnis yang dijalankan di Ponpes Darul Yatama Wal Masakin (Dayama) - Jerowaru Kabupaten Lombok Timur. Pemiliban lokasi penelitian dilakukan secara sengaja (purposive) dengan pertimbangan bahwa Ponpes Dayama merupakan salah satu ponpes tertua dan terbesar di Kabupaten Lombok Timur, serta satu-satunya ponpes dengan lahan agribisnis terluas. Sampel responden diambil dari pengurus yayasan dan petani pengelola sebanyak 30 orang responden. Dalam penelitian ini ada tiga kegiatan agribisnis yang diamati yakni pertanian, peternakan, dan perikanan. Dari hasil penelitian didapatkan bahwa, model keewirausahaan pada kegiatan bidang pertanian yakni dengan model Sakap (bagi hasil), model kewirausabaan pada kegiatan peternakan yakni dengan model kadasan dengan pola pengelolaan kandang kolektif dan perguliran. Dan model kewirausabaan pada kegiatan perikanan adalah dengan model swakelola (pengelolaan lansung).
\end{abstract}

Kata Kunci: Model, kewirausahaan, agribisnis, pengelolaan

\section{LATAR BELAKANG}

Indonesia sebagai negara dengan jumlah penduduk terbesar keempat di dunia setelah Republik Rakyat Tiongkok, India, dan Amerika Serikat merupakan pasar yang sangat menjanjikan bagi negara lain. Dengan adanya kebijakan regional negara-negara asia tenggara (Asean) melalui Masyarakat Ekonomi Asean (MEA), menjadikan peluang Indonesia untuk bersaing dengan negara-negara lain terbuka lebar, namun disisi lain menyisakan suatu permasalahan yakni sampai sejauh manakah kesiapan Indonesia untuk dapat bersaing dengan negara lain? Inilah pertanyaanya. Jika tidak memiliki kompetensi maka tentu Indonesia hanya akan dijadikan sebagai pasar bagi negara-negara lain, dan bangsa Indonesia hanya akan jadi penonton dinegerinya sendiri. 
M. Nashruddin | Model Kewirausahaan Agribisnis Pada Yayasan Pondok Pesantren Darul Yatama Wal Masakin (Yaponpes-Dayama)) Jerowaru- Lombok Timur

Untuk itu maka, Indonesia harus memanfaatkan semua potensi yang dimiliki untuk dapat bersaing seperti, potensi sumberdaya alam dan potensi sumberdaya manusia. Terkait dengan potensi sumberdaya manusia maka, manusia-manusia Indonesia harus betul-betul dipersiapkan dengan kemampuan keterampilan yang mumpuni untuk dapat bersaing dengan negara lain, yakni dengan cara menumbuhkan semangat kewirausahaan pada semua level dan status anak bangsa. Kewirausahaan, merupakan upaya untuk melihat dan mengambil kesempatan-kesempatan (peluang) bisnis serta kemampuan mengoptimalisasikan segala bentuk sumberdaya untuk digunakan dalam rangka mengoptimalkan suatu kegiatan bisnis.

Kegiatan pendidikan kewirausahaan saat ini bukan hanya domain perguruan tinggi atau lembaga pendidikan formal, namun juga dapat dipraktekkan di pondok-pondok pesantren yang merupakan lembaga yang telah mengakar selama berabad-abad di masyarakat Indonesia. Pesantren sebagai lembaga pendidikan nonformal saat ini jumlah nya di Indonesia terus meningkat pesat, berdasarkan data Direktorat Pendidikan Diniyah dan Pondok Peantren departemen Agama RI tahun 2011 terdapat 14.656 pesantren di Indonesia dengan jumlah santri 9,5 juta. Alumninya mencapai puluhan juta orang tersebar diseluruh pelosok tanah air. (Madekhan dan Churiyah, 2012) . Madekhan dan Churiyah (2012), juga menambahkan bahwa pesantren saat ini sudah membekali santrinnya selain ilmu agama, juga kecakapan hidup (life skill atau life competency) yang sesuai dengan lingkungan kehidupan dan kebutuhan santri yaitu salah satunya adalah pendidikan dan pengembangan kewirausahaan.

Pesantren saat ini menurut Mahduri (2002) dalam Solichah (2011), bukan hanya sebagai lembaga pendikan yang bergerak di bidang agama, melainkan sebagai lembaga pendikan yang responsif akan problematika ekonomi di Indonesia.

Sebagai lembaga yang telah mengakar di tengah-tengah masyarakat dari sejak zaman pra kemerdekaan, tentunya pondok pesanatren telah memahami betul kondisi kebutuhan masyarakat baik aspek ruhiyah, aspek jasadiyah, maupun aspek maliyah. Untuk itu tentunya pesantren yang tanggap harus segera memanfaatkan potensi yang dimiliki semaksimal mungkin untuk dapat mengkaryakan diri di tengah masyarakat, membimbing dan membina masyarakat untuk dapat hidup lebih mandiri dan sejahtera.

Secara substansial, pesantren merupakan institusi keagamaan yang tidak mungkin dilepaskan dari masyarakat, khususnya pedesaan. Lembaga ini tumbuh dan berkembang dari dan untuk masyarakat yang memposisikan dirinya sebagai bagian masyarakat dalam 
M. Nashruddin | Model Kewirausahaan Agribisnis Pada Yayasan Pondok Pesantren Darul Yatama Wal Masakin (Yaponpes-Dayama)) Jerowaru- Lombok Timur

pengertian yang transformatif. Dalam konteks ini, pendidikan pesantren pada dasarnya merupakan pendidikan yang sarat dengan nuansa transformasi sosial. Pesantren berikhtiar meletakkan visi dan kiprahnya dalam kerangka pengabdian sosial yang pada mulanya ditekankan kepada pembentukan moral keagamaan dan kemudian dikembangkan kepada rintisan-rintisan pengembangan yang lebih sistematis dan terpadu (Saefudin 2008, dalam Wahyono, 2010).

Menyadari begitu besar tanggung jawab kemasyarakatan yang diemban psenatren maka, tentunya kiprah pesantren dalam membina masyarakat sangat diharapkan. Karena selain hidup ditengah masyarakat pesantren juga dilahirkan dari rahim masyarakat yang haus akan tuntutan pengayoman. Karena lahir dari dan untuk masyarakat maka tentu semua persoalan keemasyarakatan tidak ada yang lebih memahami selain pesantren. Untuk itu pesantren betul-betul diharapkan sebagai garda terdepan pembinaan masyarakat.

Yayasan Pondok Pesantren Darul Yatama Wal Masakin (Yaponpes-Dayama) merupakan salah satu pesantren yang telah berusia puluhan tahun. Sebagai salah satu Ponpes terbesar di Kabupaten Lombok Timur tentunya juga diharappkan mampu menjadi agen perubahan ditengah-tengah masyarakat. Saat ini, Ponpes Dayama telah memiliki beberapa kegiatan kewirausahaan dibidang pertanian, perikanan dan pertenakan. Aset Ponpes Dayama tersebar di beberapa wilayah di Kecamatan Jerowaru berupa sawah, ladang, tambak, dan peternakan yang telah. dijadikan sebagai sumber pembiayaan kegiatan di Ponpes.

Dengan asset yang cukup besar tersebut maka dipandang perlu untuk mengetahui bagaimana model pengelolaan kewirausahaan agribisnis yang dijalankan Ponpes Dayama dalam rangka pembinaan ekonomi masyarakat.

\section{RUMUSAN MASALAH}

Berdasarkan latar belakang tersebut di atas maka dapat dirumuskan masalah dalam penelitian ini adalah bagaimanakah model kewirausahaan agribisnis Pada Yayasan Pondok Pesantren Darul Yatama Wal Masakin (Yaponpes-Dayama) Jerowaru- Lombok Timur.

\section{TUJUAN PENELITIAN}

Tujuan dari penelitian ini adalah untuk mengetahui model kewirausahaan agribisnis pada Yayasan Pondok Pesantren Darul Yatama Wal Masakin (Yaponpes-Dayama) Jerowaru- Lombok Timur 
M. Nashruddin | Model Kewirausahaan Agribisnis Pada Yayasan Pondok Pesantren Darul Yatama Wal Masakin (Yaponpes-Dayama)) Jerowaru- Lombok Timur

\section{MANFAAT PENELITIAN}

Penelitian ini diharapkan dapat sebagai bahan referensi atau pembanding bagi instansi lain khususnya pondok pesantren dalam mengembangkan model kewirasuahaan agirbisnis di masingmasing instansi.

\section{METODOLOGI}

Jenis penelitian ini adalah penelitian deskriptif-kualitatif, yaitu penelitian yang mendeskripsikan suatu gejala atau penomena sehinga pembaca memiliki gambaran yang jelas atas penomena atau gejala tersebut. Penentuan Ponpes Dayama dilakukan secara sengaja (purposive) dengan pertimbangan bahwa Ponpes Dayama merupakan salah satu ponpes tertua dan terbesar di Kabupaten Lombok Timur, dan satu-satunya ponpes dengan lahan agribisnis terluas. Teknik pengumpulan data dengan wawancara mendalam dan studi dokumentasi. Penentuan responden dilakukan secara quota yakni sebanyak 30 orang yang terdiri dari pengurus yayasan dan petani penggarap/peternak.

\section{HASIL DAN PEMBAHASAN}

Ponpes Dayama didirikan pada tangga 16 November 1973. Sejak didirikan ponpes Dayama telah berkiprah membangun masyarakat melalui berbagai macam kegiatan, seperti kegiatan pendidikan yakni melalui madrasah ibtiida’iyah (MI), pendidikan madrasah tsanawiyah (MTs), pendidikan madrasah aliyah (MA), pendidikan diniyah islamiyah, majelis taklim, panti asuhan, dan kegiatan kewirausahan berupa kegiatan pertanian, perikanan, dan peternakan. Penyelenggaraan pendidikan di Ponpes Dayama dilakukan dengan penggabungan cara tradisional dan dan dengan pola-pola pendidikan modern. Penyelenggaraan pendidikan tradisional yakni melalui pendidikan diniyah islamiyah yang merupakan lembaga pendidikan informal. Pendidikan dilakukan sore hari dengan membahas kitab-kitab klasik yang selama ini selalu menjadi peganngan pondok pesantren, sedangkan pendidikan formal diselenggaran melalui lembagalembaga pendidikan yang telah resmi terdaftar dikementerian keagamaan dengan menerapkan standar kurikulum kementerian keagamaan. Selain mengikuti pendidikan dilingkup pondok, santri Ponpes Dayama juga melakukan kegiatan mengaji kitab dengan mendatangi para guru ngaji kerumahnya masing-masing dengan membahas kitab-kitab klasik. Lokasi penyelenggaraan 
M. Nashruddin | Model Kewirausahaan Agribisnis Pada Yayasan Pondok Pesantren Darul Yatama Wal Masakin (Yaponpes-Dayama)) Jerowaru- Lombok Timur

pendidikan pada Ponpes Dayama dikonsentrasikan pada dua tempat yakni di Jalan Tete Batu Desa Jerowaru dan di Mengkuru Desa Pandan Wangi Kecamatan Jerowaru Kabupaten Lombok Timur. Pada kegiatan kewirausahaan pertanian, perikanan, dan peternakan, telah dikembangkan beberapa model usaha yang dilakukan Ponpes Dayama untuk mampu memberdayakan potensi yang dimilki secara optimal. Adapun model kewirausahaan agribisnis yang telah dikembangkan Ponpes Dayama pada tiga aspek tersebut yakni:

\section{Kegiatan pertanian}

Dalam kegiatan pertanian, berdasarkan data yang didapatkan dari pengurus ponpes, saat ini Ponpes Dayama mengelola lahan pertanian berupa sawah dan ladang. Luas sawah yang dikelola yakni seluas 9 hektar, dan ladang seluas 17 hektar. Dari 9 hektar sawah tersebut, 2 hektar merupakan sawah yang dikuasai dengan sistem sewa dari penduduk. Keberadaan sawah yang dikuasai oleh Yayasan Dayama baik yang merupakan asset milik yayasan maupun yang berstatus sewa menyebar dibeberapa kesubakan di wilayah Kecamatan Jerowaru. Dari wawancara yang dilakukan dengan pengurus yayasan diketahui bahwa model pengelolaan sawah tersebut diserahkan kepada masyarakat dengan sistem sakap (hak garap). Untuk lahan sawah ada 7 orang masyarakat yang diserahi untuk menggarap. Sedangkan lahan ladang ada 5 orang penggarap. Adapun ketentuan dalam sistem sakap ini adalah bagi hasil yakni bahwa, jika pembiayaan berasal dari penyakap maka sistem bagi hasilnya adalah 2:1, yakni dua bagian untuk penyakap dan satu bagian untuk yayasan, sedangkan bila pembiayaannya dibagi rata, maka hasilnya juga dibagi rata, begitu juga sebaliknya. Dalam praktiknya selama ini lebih banyak pembiayaan usaha tani dilakukan oleh yayasan, petani penggarap hanya memelihara saja. Berdasarkan data hasil interview dengan pengurus yayasan diketahui bahwa, setiap tahunnya hasil panen berupa padi pada lahan sawah seluas 9 hektar tersebut kurang lebih 7-8 ton per hektar atau sebanyak 56 ton - 72 ton secara keseluruhan. Berdasarkan kesepakatan sistem bagi hasil dengan pembiayan penuh dari yayasan maka setiap tahunnya Ponpes Dayama mendapatkan pembagian kurang lebih 37 ton-48 ton. Sedangkan penggarap mendapatkan bagian 16,33 ton - 24 ton. Dari hasil pembagian tersebut oleh pengurus yayasan ada yang dijual dan ada yang disimpan, tergantung pada hasil musyarah yayasan. Dari total produksi yang dihasilkan dengan menaman benih padi unggul sudah termasuk hasil yang optimal, namun karena kemajuan dan perkembangan teknologi yang mampu meningkatkan optimalisasi lahan, maka pengurus yayasan beserta petani penggarap juga menghendaki agar lahan usaha tani yayasan dapat meningkat produksinya. Untuk itu Ponpes 
M. Nashruddin | Model Kewirausahaan Agribisnis Pada Yayasan Pondok Pesantren Darul Yatama Wal Masakin (Yaponpes-Dayama)) Jerowaru- Lombok Timur

Dayama telah melakukan sistem pengelolaan lahan dengan cara sebagai berikut: Pertama; optimalisasi penggunaan pupuk dan pestisida, yakni dengan cara tidak melakukan pemupukan secara berlebih, namun sesuai dengan takaran yang direkomendasikan oleh penyuluh pertanian yakni urea $200 \mathrm{~kg} / \mathrm{ha}$, SP36 $100 \mathrm{~kg} / \mathrm{ha}$, phonska 300kg/ha dan pupuk organik $500 \mathrm{~kg} / \mathrm{ha}$, hal ini juga sejalan seperti penjelasan yang diberikan Ihsan (2012), dalam artikelnya yang berjudul Aplikasi Dan Dosis Pupuk Padi. Sedangkan penggunaan pestisida disesuaikan dengan volume serangan hama atau penyakit pada tanaman. Dengan adanya optimalisasi penggunaan pupuk dan pestisida ini maka, penggunaan pupuk dan pestisida yang selama ini cenderung berlebihan dapat dihindari, sehingga yayasan dapat mengurangi biaya tinggi dan menghindari kerusakan lahan.

Kedua; Adopsi teknologi pola tanam jajar legowo. Berdasarkan data yang disampaikan oleh pengurus yayasan dan petani penggarap, mereka mengatakan bahwa saat ini mereka telah melakukan adopsi teknologi berupa bertani dengan pola tanam jajar legowo. Ada sebagian penggarap yang mengatakan menggunakan jajar legowo 1:4, 1:6, dan 1: 8, namun secara umum mereka menggunakan jajar legowo 1:6. Dari penjelasan pengurus yayasan dan petani penggarap diketahui juga bahwa dengan pola tanam jajar legowo ini mereka merasa memiliki banyak kemudahan yakni kemudahan dalam perawatan, dan adanya pengnghematan dalam penggunaan benih yakni antar 10\%-20\%.

Ketiga; menanam benih hibrida. Selain menggunakan pola tanam jajar legowo, pengelolaan lahan sawah Ponpes Dayama dengan menanam benih hibrida. Jenis benih hibrida yang dipilih adalah jenis Sembada B9. Penggunaan benih hibrida sudah sudah dua tahun ditanam pada lahan Ponpes Dayama yakni mulai dari musim tanam tahun 2013 dan musim tanam tahun 2014, dan hasilnya terjadi peningkatan produksi lahan 20\%-30\% dari penggunaan benih unggul.

Dengan adanya beberapa pola pengelolaan lahan yang dilakukan pengurus yayasan dan petani penggarap pada lahan sawah Ponpes Dayama, tingkat produktifitas lahan dalam 2 tahun terakhir ini mengalami peningkatan yang semula rata-rata produksi per hektar 7 ton -8 ton, meningkat menjadi 9-10 ton/ha.

Selain lahan sawah, Yaponpes Dayama juga memiliki ladang seluas 17 hektar yang berlokasi di Desa Pemongkong Kecamatan Jerowaru. Ladang ini hanya dapat ditanam pada musim hujan, sehingga untuk dapat meningkatkan nilai guna lahan pengurus yayasan memutuskan pola pengelolaan lahan tersebut dengan ditanami tanaman tahunan yakni tanaman pohon jati dan mahoni yang dianggap bernilai ekonomis tinggi, sedangkan sela-sela pohon 
M. Nashruddin | Model Kewirausahaan Agribisnis Pada Yayasan Pondok Pesantren Darul Yatama Wal Masakin (Yaponpes-Dayama)) Jerowaru- Lombok Timur

tersebut tetap diberikan kepada masyarakat untuk menanam tanaman semusim tanpa dengan meminta bagi hasil. Asakan masyarakat tetap memelihara keberadaan tanaman jati dan mahoni tersebut.

\section{Peternakan}

Saat ini Ponpes Dayama telah mengelola usaha peternakan yakni berupa ternak sapi dan kerbau. Berdasarkan hasil wawancara dengan pengurus yayasan, model kewirausahaan peternakan pada Ponpes Dayama adalah dengan sistem kadasan, yakni pengurus yayasan memberikan kepada masyarakat untuk memeliharanya dengan cara bagi hasil, ketentuannya yakni, anak pertama untuk peternak, dan anak keduanya untuk pemilik atau yayasan.

Dari sejak mulai melakukan wirausaha peternakan ini pada tahun 2008 dengan jumlah ternak awal sebanyak 93 ekor, menurut penjelasan pengurus yayasan, sampai saat ini Ponpes Dayama telah memiliki ternak sapi sebanyak 354 ekor, baik yang berasal dari hasil bagi hasil maupun penambahan dari usaha lain, sedangkan ternak kerbau baru diadakan pada tahun 2013 sebanyak 30 ekor dan saat ini telah berkembang menjadi 39 ekor.

Untuk menjaga keamanan ternak, pola pengelolaan dilakukan dengan sistem pengandangan kolektif, sapi maupun kerbau dikelompokkan berdasarkan sebaran wilayah tertentu, yakni daerah sentra domisili peternaknya. Terdapat 2 titik kandang kolektif untuk sapi yakni di komplek Dusun Surelalem desa Pemongkong Kecamatan Jerowaru, di komplek ini dikandangkan sebanyak 101 ekor sapi, dan sebanyak 39 ekor kerbau, selanjutnya di Komplek Kandang Paek Desa Pandan Wangi Kecamatan Jerowaru sebanyak 253 ekor sapi. Pola komplek ini ditempuh selain untuk menjaga keamanan juga untuk memanfaatkan kotoran ternak untuk dijadikan sebagai pupuk, walaupun saat ini pemanfaatan dan pengolahannya masih belum berjalan secara optimal.

Untuk menjaga kontiniutas pemeliharaan, yayasan juga melakukan pengguliran kadasan di tengah masyarakat, yakni dengan menyebarkan ke masyarakat yang lain, apabila ada populasi ternak yang lebih dari 5 ekor pada salah satu peternak biasanya sebagian ternak kalau tidak dijual atau dipotong akan dikadaskan lagi pada masyarakat atau peternak yang lain. Hal ini memang masih tergantung dari kesanggupan pemeliharaan oleh peternak itu sendiri. Jika jumlah tersebut dianggap masih bisa untuk dia kelola atau pelihara maka walaupun jumlah ternak yang ada padanya sudah lebih dari lima akan tetap diberikan untuk dipelihara sendiri. 
M. Nashruddin | Model Kewirausahaan Agribisnis Pada Yayasan Pondok Pesantren Darul Yatama Wal Masakin (Yaponpes-Dayama)) Jerowaru- Lombok Timur

Selain dalam bentuk bagi hasil anakan, sebagai bentuk tanggung jawab yayasan kepada peternaknya, dalam setiap tahun yayasan juga beberapa kali memberikan subsidi kepada peternaknya berupa bahan-bahan makanan, pakaian, dan alat-alat kebutuhan peternakan, seperti senter, sabit, dan lain sebagainya.

\section{Perikanan}

Ponpes Dayama memiliki lahan tambak seluas kurang lebih seluas 8 hektar yang terletak di Tuwaswas Desa Pemongkong Kecamatan Jerowaru.

Untuk kegiatan perikanan, model pengelolaan kewirausahaan agribisnis yang dijalankan oleh Yaponpes Dayama adalah dengan pengelolaan secara lansung atau mandiri oleh pengurus yayasan dengan pola tambak tradisional. Dalam pengelolaan tambak ini, untuk urusan pengadaan sarana produksi sampai pada pemasarannya tetap ditangani oleh pengurus yayasan, sedangkan untuk kegiatan pemeliharaan sehari-hari dan keamanan diberikan kepada satu atau dua orang masyarakat sebagai penunggu atau pemelihara dengan sistem upah. Pengurus yayasan memberikan upah dan sangu bulanan.

Model pengelolaan lahan tambak Ponpes Dayama masih dengan pola pertambakan tradisional karena dalam pemeliharaan dan penataan areal pertambakan belum sesuai dengan petunjuk penerapan teknologi pertambakan. Jenis ikan yang ditebar selama ini adalah ikan bandeng, dengan padat tebar yang tidak proporsional, kadang terlalu padat kadang juga terlalu jarang, tergantung pada jumlah nener hasil tangkapan masyarakat yang ditangkap dari alam. Padahal ukuran ideal padat tebar ikan bandeng adalah 2500 - 5000 ekor nener per hektar.

Pengusahaan komoditas bandeng karena dianggap pengelolaannya paling mudah, biasanya ikan bandeng bisa tumbuh dengan sendirinya tanpa diberikan perlakuan apa pun, seperti kincir aerator, pemupukan, dan tanpa diberikan pakan tambahan. Walaupun hal ini tentunya sangat jauh dari ideal.

Pada tambak Yayasan Ponpes Dayama pakan bandeng hanya berasal dari pakan alami tanpa diberikan pakan buatan. Perlakuan hanya diberikan berupa regulasi pengairan yang tetap dikontrol terutama pada musim penghujan dan musim kering. Ini untuk menghindari agar jangan sampai suplai air tawar terlalu banyak pada saat musim hujan karena areal pertmabakan terletak diantara kiri-kanan bukit. Sebaliknya kontrol supali air pada musim kemarau dilakaukan agar jangan sampai suplai air laut terlalu kurang. Pengaturan supalai air inilah yang menjadi satu- 
M. Nashruddin | Model Kewirausahaan Agribisnis Pada Yayasan Pondok Pesantren Darul Yatama Wal Masakin (Yaponpes-Dayama)) Jerowaru- Lombok Timur

satunya sistem pembaharuan nutrient dan hara perairan sebagi sumber pakan bagi biota peliharaan.

Berdasarkan hasil observasi peneliti, kondisi penataan tambak masih jauh dari ideal, sebagai contoh sistem sirkulasi air, tidak ditata sedemikian rupa sehingga surkulasi air berjalan baik pada saat pasang tinggi maupun pasang rendah, termasuk juga pada saat musim penghujan dan musim kemarau. Sehingga harus selalu diberi perlakuan setiap perubahan musim. Demikian juga petakan tambak yang tidak tertata rapi serhingga menimbulkan kesan tidak terurus. Kondisi ini menyebabkan hasil usaha agribisnis dari tambak yang dikelola Yayasan Ponpes Dayama masih jauh dari optimal yakni hanya 200-250 Kg per hektar. Padahal ukuran ideal untuk pertambakan dengan luas satu hektar jika dikelola dengan system intensif bisa mencapai produksi $900 \mathrm{~kg}$ per hektar.

\section{SIMPULAN DAN SARAN}

\section{Simpulan}

Dari hasil temuan penelitian tersebut di atas diketahui bahwa model kewirausahaan agribisnis yang dijalankan pada Yaponpes Dayama pada kegiatan pertania, yakni dengan sistem sakap dengan pola pengelolaan berupa; optimalisasi penggunaan pupuk dan pestisida, menanam benih hibirda, dan adopsi pola tanam dengan sistem jajar legowo. Untuk kegiatan peternakan model kewirausahaan yang dijalankan yakni model kadasan dengan pola pengelolaan kandang kolektif dan perguliran. Sedangkan model kewirausahaan pada kegiatan perikanan yakni secara swakelola dengan pola pengelolaan dengan sistem pertambakan tradisional.

\section{Saran}

1. Diharapakn Pondok Pesantren Dayama tidak hanya fokus melakukan pembinaan kewirausahaan pada masyarakat umum, namun juga perlu adanya pembinaan jiwa enterprenurship kepada peserta didik yang bernaung pada lembaga pendidikan Yaponpes Darul Yatama Wal Masakin.

2. Perlu adanya kemitraan yang dibangun Ponpes Dayama dengan lembaga-lembaga agribisnis untuk meningkatkan pengelolaan kegitan kewirausahaan agribisnis di Ponpes Dayama. 
M. Nashruddin | Model Kewirausahaan Agribisnis Pada Yayasan Pondok Pesantren Darul Yatama Wal Masakin (Yaponpes-Dayama)) Jerowaru- Lombok Timur

\section{DAFTAR PUSTAKA}

Madekhan, Churiyah dan Madziatul. 2012. Pola dan Muatan Pembelajaran Kewirausahaan di Pondok Pesantren Jawa Timur. Jurnal Ekonomi Bisnis Tabun 17, Nomor 1, Maret 2012:89.https://jurusanmanajemenfeum.files.wordpress.com (diakses 10April 2016).

Nurman, Ihsan, 2012. Aplikasi Dan Dosis Pupuk Padi. https:// ceritanurmanadi. wordpress.com (diakses 18 April 2016).

Sholichah, Dewi Chalimatus, 2011. Pengarub Pendidikan Wirausaba Agribisnis Terhadap Kompetensi Wirausaha Santri Pada Usaba Sapi Potong (Kasus: Pesantren Wirausaha Agrobisnis Abdurrabman Bin Auf, Desa Bulan, Wonosari, Klaten, Jawa Tengah) Skripsi. Departemen Sains Komunikasi Dan Pengembangan Masyarakat Fakultas Ekologi Manusia Institut Pertanian Bogor. http :// repository. ipb.ac.id (diakses 12 April 2016).

Wahyono, Sigit. 2010. Inovasi Hidden Curriculum Pada Pesantren Berbasis Entrepreneurship (Studi Kasus di Pondok Pesantren Al-Isti'anah Plangitan Pati). Fakultas Tarbiyah Institut Agama Islam Negeri Walisongo Semarang. http://library.walisongo.ac.id (diakses 12 Maret 2016) 